DOI: $10.31393 /$ reports-vnmedical-2020-24(1)-33

UDC: $616.71007 .234: 577.161 .2$

\title{
THE RESULTS OF THE ASSESSMENT OF THE CONDITION AT THE TIME OF ADMISSION TO THE HOSPITAL, THE FUNCTIONAL RESULT AT THE TIME OF DISCHARGE AND PLANNING OF THE OUTPATIENT STAGE IN STROKE PATIENTS ACCORDING TO THE REGISTER OF HOSPITALS IN VINNYTSIA FOR 2017-2019
}

Fiks D. 0 .

National Pirogov Memorial Medical University (Pirogov st., 56, Vinnytsya, Ukraine, 21018)

Received November 01, 2019; Accepted December 23, 2019

Responsible for correspondence: e-mail: d.fix@i.ua

Annotation. Improving approaches to the diagnosis, treatment and rehabilitation of stroke is a priority, as this disease is not only a medical but also a social problem. The purpose of the work is to assess the dynamics of the indicators at the time of admission to the hospital, the functional result at the time of discharge and planning of the outpatient stage in stroke patients of hospitals in Vinnytsia for the period 2017-2019. The stroke register is formed on the basis of medical documentation of medical institutions, which are the most typical for this region of Ukraine. Statistical processing of the results was performed using the licensed statistical package "Statistica 5.5" using parametric evaluation methods. Significant differences in the indicators of the effectiveness of the organization of medical care for stroke at the pre-hospital and hospital stage between the two medical institutions of Vinnytsia, as well as in the dynamics of observation time. The positive and negative aspects of medical and diagnostic work of these hospitals are analyzed. A number of factors influencing the success of treatment outcome and comprehensive rehabilitation of stroke patients are analyzed. Modern views on the problem of analysis of clinical data using the method of register and medical statistics are presented.

Keywords: stroke, Glasgow com scale, NIHSS stroke scale, carotid angioplasty, functional gait test, neurorehabilitation.

\section{Introduction}

Considering that the consequences of acute cerebrovascular accident (ACA) are a significant percentage of disability, a long period of social and labor rehabilitation, this disease is not only a medical but also a social problem. Therefore, improving approaches to diagnosis, therapy, rehabilitation of stroke is a priority $[2,16,26]$.

Modern practice of stroke is impossible without constant monitoring of key indicators of the patient's condition. Assessment of the patient's level of consciousness is a mandatory and priority stage in the neurological examination. Appropriate scales are used to objectify the patient's condition, assess the dynamics and severity of the disease, optimize the processes of diagnosis and treatment, to standardize the statanalysis of clinical data $[1,3]$. The latter provide an opportunity to unify approaches to a comprehensive assessment of the patient's condition, help to make objective decisions about the duration of treatment of the patient in the hospital, movement from one unit to another and discharge from the department [10].

The Glasgow com scale is designed to assess the level of consciousness of patients, the degree of its progression or regression. The scale is used to predict the functional outcome and survival of patients with acute cerebral circulatory disorders [6, 20]. The NIHSS stroke scale is validated, has retest reliability, does not require a long time to complete and allows you to get a complete picture of the patient in a short time [1].

It is established that 32 thousand neurons, 230 million synapses are irreversibly destroyed in 1 second of ACA development, almost 2 million brain cells and 14 billion synapses are destroyed in 1 minute. In an hour of stroke development, the patient loses 120 million cells, 830 billion synapses. During the entire period of the disease, an average of 1.2 billion neurons and 8.3 billion cellular connections are lost [12]. It is extremely important to take a patient with ACA to the hospital as early as possible, even when the onset of symptoms is unknown.

Recovery after ACA is a complex biological process, the speed and vector of which is influenced by many factors [16]. The degree of recovery of lost functions after a stroke depends on the timing of the onset and continuity of rehabilitation measures [4]. Studies have shown that with timely and adequate rehabilitation, the effectiveness of recovery of neurological disorders significantly exceeds the same rate in the group without rehabilitation, helps to reduce anxiety. It was determined that a significant proportion of patients returned to work and normal life after rehabilitation therapy [26]. In most hospitals at the time of discharge using the test "10 meters" is an assessment of the effectiveness of treatment and rehabilitation of patients, predicting the restoration of lost motor and coordination functions.

An important role among the factors that determine the future fate and quality of life of patients who have suffered a stroke, play the strategy of outpatient (post-hospital) management of patients [23]. Quality outpatient care helps reduce mortality, disability and the economic burden of the disease for the patient's family and society as a whole. Unfortunately, a small proportion of stroke patients after discharge from the hospital are in specialized rehabilitation centers. The task of caring for this category of patients is 
transmitted to relatives of the patient, and the supervision outpatient medical units.

Of course, secondary prevention of strokes is carried out as part of comprehensive rehabilitation of patients who have undergone ACA. According to a number of stroke registries, recurrent strokes during the first seven years occur in a third of patients, almost $50 \%$ of them - during the first year. The probability of death, the degree of loss of neurological functions and, accordingly, the level of disability in repeated ACA is much higher than in the first episode [21].

Thus, in order to be able to objectively choose a treatment strategy, assess the effectiveness and costeffectiveness of a method of treatment of ACA, increase the reliability of health care resource planning, it is necessary to analyze key factors determining stroke outcomes, including clinical features of the patient. admission, functional outcome at discharge, features of the organization of inpatient and outpatient care.

The purpose of the work - to assess the dynamics of indicators at the time of admission to the hospital, the functional result at the time of discharge and planning of the outpatient stage in stroke patients of hospitals in Vinnytsia for the period 2017-2019.

\section{Materials and methods}

The stroke register is formed on the basis of medical documentation of medical institutions, which are the most typical for this region of Ukraine. A retrospective analysis of the results of medical histories of patients hospitalized according to the indications in an emergency to the stroke unit of the municipal non-profit enterprise "Vinnytsia Regional Clinical Psychoneurological Hospital named after Academician O. I. Yushchenko of Vinnytsia Regional Council" (VRCPNH) or Vinnytsia City Clinical Hospital of Emergency Medical Services (VCCHEMS) for the period 2017-2019 with a diagnosis of ACA (Table 1). After inpatient treatment, the RES-Q report form was completed on a caseby-case basis - a special report forms in an international

Table 1. Quantitative distribution of men and women with ACA in the stroke unit of VRCPNH or VCCHEMS for 2017-2019.

\begin{tabular}{|c|c|c|c|c|c|}
\hline \multirow{2}{*}{$\begin{array}{c}\text { Groups } \\
\text { surveyed }\end{array}$} & \multirow{2}{*}{ Years of research } & \multicolumn{4}{|c|}{ Hospitals } \\
\cline { 3 - 6 } & & \multicolumn{2}{|c|}{ VRCPNH } & \multicolumn{2}{c|}{ VCCHEMS } \\
\cline { 3 - 6 } & & men & women & men & women \\
\hline \multirow{4}{*}{\begin{tabular}{c} 
General \\
\cline { 2 - 6 }
\end{tabular}} & 2017 & 307 & 209 & 351 & 335 \\
\cline { 2 - 6 } & 2018 & 312 & 187 & 310 & 306 \\
\hline \multirow{3}{*}{$\begin{array}{c}\text { Ischemic } \\
\text { stroke }\end{array}$} & 10 months of 2019 & 287 & 175 & 182 & 163 \\
\cline { 2 - 6 } & 2017 & 269 & 184 & 308 & 296 \\
\cline { 2 - 6 } & 2018 & 267 & 166 & 276 & 282 \\
\hline \multirow{3}{*}{$\begin{array}{c}\text { Hemorrhagic } \\
\text { stroke }\end{array}$} & 10 months of 2019 & 248 & 152 & 162 & 153 \\
\cline { 2 - 6 } & 2017 & 37 & 25 & 42 & 39 \\
\cline { 2 - 6 } & 2018 & 45 & 21 & 34 & 24 \\
\hline
\end{tabular}

program developed by the European Stroke Society (ESO) ESO-EAST initiative. The hospitals we surveyed have been participating in this program since 2017 . From the data of RES-Q (version 1.0) it is possible to receive information both on clinical parameters of a case of a stroke, and time indicators of performance of separate procedures characterizing quality of work of medical institution.

The average age of patients in VRCPNH was: in men $62.40 \pm 0.59$ in 2017, 60.85 \pm 0.59 in 2018 and $61.24 \pm 0.57$ in 2019; in women - $66.48 \pm 0.79$ in $2017,65.54 \pm 0.65$ in 2018 and $64.41 \pm 0.84$ in 2019 . The mean age of patients in VCCHEMS was: in men $-67.18 \pm 0.60$ in $2017,67.10 \pm 0.64$ in 2018 and $67.66 \pm 0.78$ in 2019 ; in women - $72.53 \pm 0.54$ in 2017, 72.01 \pm 0.59 in 2018 and $72.67 \pm 0.82$ in 2019 .

The neurological status of patients was assessed using a modified NIHSS scale, which includes 15 consecutive points and is calculated in points. The scale was used to assess the following CNS functions: level of consciousness, answers to questions, tasks, oculomotor disorders, hemianopsia, facial muscle weakness, movements in the right and left extremities, ataxia, sensitivity disorders, speech and different types of perception [19]. Accordingly, the severity of the stroke was determined: satisfactory condition - 0 points, mild stroke - 1-4 points, moderate - 5-15 points, the condition between moderate and severe - 16-20 points, severe - 21-42 points.

The degree of patient disturbance was assessed using the Glasgow com scale. It contains a quantitative (score) assessment of eye opening, motor and verbal reaction and gives a qualitative assessment of the severity of ACA (consciousness, stun, sopor, coma) [18].

Given the importance of recording the time when a patient had a stroke [24], the average time from the last time there were no symptoms to the time of hospitalization and the percentage of patients admitted to the hospital after a certain period of time (up to 1 day, 2 days, more than 2 days).

At the time of discharge, the percentage of patients who succeeded or failed to perform the "10 meters" test was determined. To prevent premature stop to the mark of 10 $\mathrm{m}$, the subjects were asked to move to the line located one meter behind the finish line. Assistance was allowed only when necessary.

To assess the consequences of treatment and the availability of comprehensive rehabilitation in the outpatient phase of patients who underwent ACA, the percentage of deaths, discharged home, transferred to another medical institution or neurorehabilitation center was determined.

Statistical processing of the results was performed using the statistical package "Statistica 5.5" (licensed № AXXR910A374605FA) using parametric evaluation methods.

\section{Results. Discussion}

The most important prognostic factor in ACA is the severity of brain damage, which can be judged by the 
severity of development and depth of neurological deficit, the degree of disturbance of consciousness. The more severe the initial injury, the worse the prognosis for the patient's life and recovery [16].

A number of studies have shown that the depth of disturbance of consciousness at the time of hospitalization is a more significant factor influencing the outcome of the disease than the time from the onset of the disease to admission to the hospital $[8,17]$. According to the study of E. N. Gusev and others [5], fatalities were observed in half of the patients admitted up to 6 hours and 7-12 hours after the onset of the first symptoms of ACA. In the study of mortality, depending on the state of consciousness at the time of hospitalization, it was determined that in similar terms, mortality among patients admitted with impaired consciousness by type of coma is $94 \%$, and sopor - $75 \%$.

When comparing the mean score on the Glasgow com scale, a better situation was found in the state of the degree of disturbance of consciousness in patients with VCCHEMS, which significantly $(p<0.05-0.01)$ greater value of this indicator (2018: men in general - 14.38 \pm 0.09 , with ischemic stroke - $14.38 \pm 0.10$ and hemorrhagic stroke 14.35 $\pm 0.30 ; 2019$ : total $-14.13 \pm 0.13$, with ischemic stroke - 14.23 \pm 0.13 ) compared with VRCPNH (2018: total $13.98 \pm 0.10$, with ischemic stroke $-14.12 \pm 0.09$ and hemorrhagic stroke - 13.11 $\pm 0.38 ; 2019$ : in general $13.71 \pm 0.10$, with ischemic stroke - 13.83 \pm 0.11 ). Also, for the period of 2017-2019, patients with VRCPNH have a negative dynamic of the average score on the Glasgow scale, which significantly $(p<0.05-0.01)$ decreased (men in general: $14.24 \pm 0.08$ in $2017,13.98 \pm 0.10$ in 2018 , $13.71 \pm 0.10$ in 2019 ; with ischemic stroke: $14.12 \pm 0.09$ in 2018 and $13.83 \pm 0.11$ in 2019). And in patients with VCCHEMS this indicator in 2018 was significantly $(p<0.05)$ higher compared to other years of observation (men in general: $14.07 \pm 0.09$ in 2017 and $14.38 \pm 0.09$ in 2018; with hemorrhagic stroke: $14.35 \pm 0.30$ in 2018 and $13.18 \pm 0.55$ in 2019).

A certain range of points on the Glasgow scale corresponds to a qualitative characteristic of the level of consciousness (15-14 points - clear consciousness, 1312 points - stun, 11-9 points - sopor, 8-3 points - coma) [24].

When comparing the percentage of patients, in a clear state of consciousness found significantly $(p<0.05)$ higher value in patients with VRCPNH (2017 - 76.6\% in women with ischemic stroke; in $2018-79.7 \%$ in women in general and $83.7 \%$ with ischemic stroke) compared with VCCHEMS (in $2017-68.2 \%$ in women with ischemic stroke; in 2018 - $68.0 \%$ in women in general and $70.2 \%$ with ischemic stroke). The percentage of patients who were in a state of concussion at the time of admission in VCCHEMS was significantly $(p<0.05-0.01)$ higher in women with ischemic stroke and lower in men with hemorrhagic stroke (2018 $29.1 \%$ in women with ischemic stroke and $14.7 \%$ in men with hemorrhagic stroke) compared to VRCPNH (2018 -
$16.3 \%$ in women with ischemic stroke and $35.6 \%$ in men with hemorrhagic stroke).

Similarly, in two comparable medical institutions in 2018 compared to 2017 there was a better situation in terms of consciousness at the time of hospitalization of the patient. This indicator in VRCPNH was also better in 2018 compared to 2019. Statistics for 2019 on VCCHEMS are not recorded, which, unfortunately, does not allow us to make a full comparative analysis.

The percentage of patients who had a clear consciousness at the time of admission to VRCPNH in 2018 was significantly $(p<0.01-0.001)$ higher than in 2017 and 2019 (in $2017-75.6 \%$ in men in general and $77.3 \%$ with ischemic stroke; in $2018-84.3 \%$ in men in general and $88.4 \%$ in ischemic stroke, $79.7 \%$ in women in general and $83.7 \%$ in ischemic stroke; in $2019-71.9 \%$ in men in general and $74.6 \%$ in ischemic stroke, $63.4 \%$ in women in general and $68.4 \%$ with ischemic stroke). In 2018, compared to 2017 and 2019, the state of sopor was observed in a significantly lower $(p<0.01-0.001)$ percentage of patients (in $2017-24.4 \%$ in men in general and $22.7 \%$ with ischemic stroke; in $2018-14.7 \%$ in men in general and $11.2 \%$ with ischemic stroke, $19.8 \%$ in women in general and $16.3 \%$ with ischemic stroke; in $2019-28.2 \%$ in men in general and $25.0 \%$ with ischemic stroke, $34.3 \%$ in women in general and $30.3 \%$ with ischemic stroke).

In 2018, a significantly higher percentage of patients was diagnosed $(p<0.001)$ compared to 2017 , who at the time of admission to VCCHEMS had a clear consciousness (2017 - 68.8 \% in men in general and $71.4 \%$ with ischemic stroke; $2018-82.9 \%$ in men in general and $70.2 \%$ with ischemic stroke) and significantly less in those who were in sopor (2017 - $29.6 \%$ in men in general and $28.2 \%$ with ischemic stroke; in $2018-15.5 \%$ in men in general and $15.6 \%$ with ischemic stroke).

S. Prabhakaran et al. [22] found that the degree of recovery of motor functions in most patients (except in extremely severe cases) is approximately $70 \%$ due to the initial degree of severity of motor disorders. The results of assessing the severity of neurological disorders on the NIHSS scale play a fairly reliable prognostic role. A higher number of points on this scale indicates a greater severity of ACA and the severity of neurological changes [24].

Thus, on the NIHSS stroke scale, a significantly higher $(p<0.05-0.01)$ value of the mean score in patients from VRCPNH found $(2017-8.753 \pm 0.320$ in men in general and $9.677 \pm 0.460$ in women in general; $2018-9.277 \pm 0.322$ in men in general, $8.853 \pm 0.340$ with ischemic stroke and $11.84 \pm 0.88$ with hemorrhagic stroke, $10.62 \pm 0.45$ in women in general and $10.23 \pm 0.47$ with ischemic stroke; in 2019 $10.32 \pm 0.37$ in men in general and $9.748 \pm 0.391$ with ischemic stroke, $11.13 \pm 0.68$ in women in general and $10.68 \pm 0.77$ with ischemic stroke) compared to VCCHEMS (2017 - 7.629 \pm 0.321 in men in general and 8.487 \pm 0.376 in women in general; in $2018-6.950 \pm 0.299$ in men in general, $6.873 \pm 0.317$ with ischemic stroke and $7.600 \pm 0.896$ with 
hemorrhagic stroke, $8.395 \pm 0.354$ in women in general and $8.290 \pm 0.363$ with ischemic stroke; in $2019-7.103 \pm 0.530$ in men in general and $5.494 \pm 0.505$ with ischemic stroke, $7.903 \pm 0.748$ in women in general and $7.542 \pm 0.712$ with ischemic stroke).

Over the years of observation, a negative dynamic of the mean score on the NIHSS stroke scale was noted. In 2019, the value of the indicator in patients in VRCPNH significantly $(p<0.05-0.001)$ increased compared to previous years (men in general $-8.753 \pm 0.320$ in 2017 , $9.277 \pm 0.322$ in $2018,10.32 \pm 0.37$ in 2019 ; men with ischemic stroke $-8.349 \pm 0.336$ in $2017,9.748 \pm 0.391$ in 2019; men with hemorrhagic stroke - 11.38 \pm 0.91 in 2017, $13.95 \pm 0.92$ in 2019; women with hemorrhagic stroke $10.79 \pm 1.04$ in $2017,12.09 \pm 0.96$ in 2019). In patients in VCCHEMS this figure in 2019 in men with hemorrhagic stroke was significantly $(p<0.05)$ higher than in 2018 (respectively $12.33 \pm 2.03$ and $7.600 \pm 0.896$ ).

Interpretation of NIHSS results according to the criteria of Brott T. et al. [11] is represented as follows: 0 points satisfactory condition; $1-4$ points - mild stroke; $5-15$ points - stroke of moderate severity; $16-20$ points - the condition between moderate and severe stroke; $21-42$ points - severe stroke. The analysis below shows that during the entire period of observation, patients with a higher degree of stroke severity were admitted to VRCPNH both in time dynamics and in comparison, with VCCHEMS.

When comparing the percentage of patients with a stroke severity of 0 points, it was found significantly $(p<0.05)$ lower in patients with VRCPNH (2017 - 0\% in men and women in general and with hemorrhagic stroke) compared with VCCHEMS (2017 - 1.7\% in men in general and $11.9 \%$ with hemorrhagic stroke, $1.8 \%$ in women in general and $15.4 \%$ with hemorrhagic stroke). The percentage of patients with VRCPNH in whom the severity of stroke was 1-4 points was significantly $(p<0.05)$ lower in men and higher in women with ischemic stroke (in $2018-23.1 \%$ in men in general and $25.5 \%$ with ischemic stroke; 2019 $19.1 \%$ in women with ischemic stroke) compared to VCCHEMS (2017 - $33.2 \%$ in men in general and $33.4 \%$ with hemorrhagic stroke; in $2019-11.1 \%$ in women with ischemic stroke).

When comparing the percentage of patients with a stroke severity of 5-15 points, it was found significantly $(p<0.05-0.001)$ higher in patients with VRCPNH (2017 $57.3 \%$ in men in general, $52.2 \%$ in women in general and $60.0 \%$ of hemorrhagic stroke; in $2018-59.9 \%$ in men in general and $59.2 \%$ in ischemic stroke; in $2019-55.1 \%$ in men in general and $56.0 \%$ in ischemic stroke, $60.0 \%$ in women in general, $60.5 \%$ with ischemic stroke and 56.5 $\%$ with hemorrhagic stroke) compared with VCCHEMS (2017 - 48.1\% in men in general, $43.8 \%$ in women in general and $25.6 \%$ with hemorrhagic stroke; in 2018 $47.7 \%$ in men in general and $47.1 \%$ with ischemic stroke; in $2019-25.3 \%$ in men in general and $25.3 \%$ with ischemic stroke, $19.6 \%$ in women in general, $20.9 \%$ with ischemic stroke and $0 \%$ with hemorrhagic stroke stroke). When comparing the percentage of patients with a stroke severity of $16-20$ points, it was found significantly $(p<0.05-0.01)$ higher in patients with VRCPNH $(2018-9.6$ $\%$ in men in general, $20.3 \%$ in women in general and 18.7 $\%$ of ischemic stroke; in $2019-13.2 \%$ in men in general and $11.3 \%$ in ischemic stroke, $13.7 \%$ in women in general and $7.9 \%$ in ischemic stroke) compared to VCCHEMS (2018 - 5.2\% in men in general, $9.8 \%$ in women in general and $9.6 \%$ with ischemic stroke; in $2019-4.4 \%$ for men in general and $3.1 \%$ with ischemic stroke, $4.3 \%$ for women in general and $3.9 \%$ with ischemic stroke).

The percentage of patients with a stroke severity of 21 42 points was significantly $(p<0.05-0.01)$ higher in patients with VRCPNH (2017 - $8.6 \%$ in women in general and 9.2 $\%$ with ischemic stroke, in $2018-5.1 \%$ in men in general; in $2019-7.7 \%$ for men in general and $6.5 \%$ with ischemic stroke, $8.0 \%$ for women in general and $7.9 \%$ with ischemic stroke) compared to VCCHEMS (2017 - $4.2 \%$ for women in general and $3.7 \%$ with ischemic stroke; $2018-1.9 \%$ for men in general; in $2019-0.5 \%$ for men in general and 0.6 $\%$ with ischemic stroke, $1.2 \%$ for women in general and $0.7 \%$ with ischemic stroke).

The percentage of patients with a severe stroke at the time of admission to VRCPNH with 0 points in 2017 was significantly $(p<0.05)$ lower than in $2018(2017-0 \%$ in men in general and with ischemic stroke; $2018-1.6 \%$ in men in general and $1.9 \%$ with ischemic stroke). In 20182019 , compared to 2017 , the severity of stroke in $16-20$ points was observed in a significantly higher $(p<0.05)$ percentage of patients (in $2017-11.5 \%$ in women in general and $10.9 \%$ with ischemic stroke; in $2018-20.3 \%$ in women in general and $18.7 \%$ with ischemic stroke; in $2019-13.7 \%$ in women in general). Significantly higher $(p<0.05-0.001)$ the percentage of men with a severity of 21 42 points was in 2019 compared to 2017 (in 2017 - $2.6 \%$ in men in general and $2.2 \%$ with ischemic stroke; in 2019 $-7.7 \%$ in men in general and $6.5 \%$ with ischemic stroke), and in women significantly $(p<0.05)$ higher than in 2018 (in $2017-9.2 \%$ in women with ischemic stroke; in $2018-3.6$ $\%$ in women with ischemic stroke). These data indicate the negative dynamics of this indicator.

The percentage of patients with a severe stroke at the time of admission to VCCHEMS was 0 points in 2017 was significantly $(p<0.05-0.01)$ lower compared to 2018-2019 (2017 - $0 \%$ in men and women with ischemic stroke; in $2018-2.5 \%$ in men with ischemic stroke, $2.1 \%$ in women with ischemic stroke; in $2019-1.3 \%$ in women with ischemic stroke). In 2017-2018, compared to 2019, the severity of stroke 1-4 points was observed in a significantly higher $(p<0.001)$ percentage of patients $(2017-31.6 \%$ in men in general and $32.6 \%$ with ischemic stroke, $29.3 \%$ in women in general and $29.7 \%$ with ischemic stroke; in $2018-33.2 \%$ in men in general and $34.4 \%$ in ischemic stroke, $25.8 \%$ in women in general and $27.0 \%$ with ischemic stroke; in $2019-16.5 \%$ in men in general and 
$17.9 \%$ in ischemic stroke, $11.0 \%$ in women in general and $11.1 \%$ with ischemic stroke). Similarly, in 2017-2018, compared to 2019 , the severity of stroke $5-15$ points was observed in a significantly higher $(p<0.001)$ percentage of patients (2017 - 48.1\% in men in general and $49.4 \%$ with ischemic stroke, $43.8 \%$ in women in general and $45.3 \%$ with ischemic stroke; in $2018-47.7 \%$ in men in general and $47.1 \%$ with ischemic stroke, $47.1 \%$ in women in general and $47.5 \%$ with ischemic stroke; in $2019-25.3 \%$ in men in general and $25.3 \%$ with ischemic stroke, $19.6 \%$ in women in general and $20.9 \%$ with ischemic stroke). Significantly lower $(p<0.05)$ was the percentage of men with a severity of $21-42$ points in 2019 compared to 2017 2018 (in 2017 - $4.2 \%$ in women in general and $3.7 \%$ with ischemic stroke; in $2018-3.6 \%$ in women in general and $3.2 \%$ with ischemic stroke; in $2019-1.2 \%$ in women in general and $0.7 \%$ with ischemic stroke).

Reducing the time of transportation to the hospital is a priority at the pre-hospital stage of stroke. Timely recognition of symptoms of acute cerebrovascular disorders in patients or others, emergency care, mode of transportation is essential. The delay in providing emergency medical care for this pathology is caused by the inability to distinguish the manifestations of stroke and call an ambulance in time, misunderstanding the severity or denial of the disease. The prognosis for recovery and life is also influenced by the delay in hospitalization of a stroke patient, delayed neuroimaging and inadequate treatment [17, 21].

Data on the fixation of the last time there were no signs of stroke can be the basis for systematic educational activities and campaigns designed to teach the population to recognize the signs of stroke in time and change attitudes towards ACA [27]. In fact, in this direction it is necessary to correct the existing shortcomings at the pre-hospital stage (primary care) in the service area of VCCHEMS, as evidenced by the following data in comparison with VRCPNH.

When comparing the mean time, when the last time there were no signs of stroke was found significantly $(p<0.05-0.001)$ greater value in patients with VCCHEMS (2017 - 14.03 \pm 0.38 in men in general and $14.30 \pm 0.40$ with ischemic stroke; in $2018-13.14 \pm 0.47$ in men in general and $13.25 \pm 0.50$ with ischemic stroke; in $2019-15.01 \pm 0.64$ in men in general and $14.95 \pm 0.68$ with ischemic stroke) compared with VRCPNH (2017 - 12.25 \pm 0.34 in men in general and $12.31 \pm 0.37$ of ischemic stroke; 2018 $11.67 \pm 0.32$ in men in general and $11.64 \pm 0.35$ with ischemic stroke; $2019-11.52 \pm 0.32$ in men in general and $11.46 \pm 0.35$ with ischemic stroke). Only in women with hemorrhagic stroke in 2017, this figure in VCCHEMS was significantly lower $(p<0.05-0.001)$ than in VRCPNH $(12.39 \pm 1.01$ and $15.25 \pm 0.94$, respectively).

During the period 2017-2019, the mean time for the last time there were no significant signs of stroke in patients with VRCPNH decreased ( $p<0.01$ ) (in women in general $13.65 \pm 0.37$ in 2017 and $11.87 \pm 0.44$ in 2019 ). In patients with VCCHEMS this indicator in 2019 was significantly $(p<0.05)$ higher than in 2018 (in men in general $13.14 \pm 0.47$ in 2018 and $15.01 \pm 0.09$ in 2019; in men with ischemic stroke $-13.25 \pm 0.50$ in 2018 and $14.95 \pm 0.68$ in 2019).

It is proved that higher efficiency of dispatching and prenotification of a medical institution about a stroke leads to a reduction of time for the arrival of an ambulance crew on call; assessment by a doctor; "door-to-needle" period; period "from the door to the imaging". Patients delivered up to 1 day after a stroke are at lower risk of death [27].

Thus, when comparing the percentage of patients who had no signs of stroke for the last time before 1 day, it was found significantly $(p<0.05-0.001)$ higher in patients with VRCPNH (2017 - 87.6\% in men in general and $86.5 \%$ with ischemic stroke, $84.7 \%$ in women in general and $84.2 \%$ with ischemic stroke; in $2018-96.2 \%$ in men in general, $95.9 \%$ with ischemic stroke and $97.8 \%$ with hemorrhagic stroke, $92.5 \%$ in women in general and $91.6 \%$ with ischemic stroke; $2019-94.8 \%$ in men in general, $94.8 \%$ in ischemic stroke and $94.9 \%$ in hemorrhagic stroke, 96.0 $\%$ in women in general and $95.4 \%$ in ischemic stroke) compared to VCCHEMS (in $2017-77.8 \%$ in men in general and $76.9 \%$ in ischemic stroke, $75.2 \%$ in women in general and $74.7 \%$ with ischemic stroke; in $2018-83.2 \%$ in men in general, $83.0 \%$ with ischemic stroke and $85.3 \%$ with hemorrhagic stroke, $81.4 \%$ in women in general and 80.5 $\%$ in ischemic stroke; in $2019-83.0 \%$ in men in general, $84.0 \%$ in ischemic stroke and $75.0 \%$ in hemorrhagic stroke, $87.7 \%$ in women in general and $87.6 \%$ in ischemic stroke).

When comparing the percentage of patients who last within 1-2 days last had no signs of stroke, we see a worse situation in VCCHEMS. In fact, this medical institution found a significantly $(p<0.05)$ higher value in patients admitted in this period $(2018-6.1 \%$ in men in general and $5.8 \%$ with ischemic stroke; in $2019-4.9 \%$ in women in general) compared to VRCPNH (2018 - $2.2 \%$ in men and $2.2 \%$ with ischemic stroke; in $2019-1.1 \%$ in women in general).

Significantly $(p<0.05-0.001)$ a higher percentage of patients admitted after the second day after the onset of stroke symptoms was found in VCCHEMS (2017 - 9.1\% in men in general and $8.8 \%$ in ischemic stroke, $15.4 \%$ in women with hemorrhagic stroke; $2018-6.1 \%$ in men in general and $6.5 \%$ with ischemic stroke) compared to VRCPNH (2017 - 4.6\% in men in general and $4.8 \%$ with ischemic stroke, $0 \%$ in women with hemorrhagic stroke; in $2018-1.0 \%$ in men in general and $1.2 \%$ with ischemic stroke).

In 2018-2019, compared to 2017, the percentage of patients who were taken to the VRCPNH within 1 day, when there were no signs of stroke for the last time, significantly increased $(p<0.05-0.001)(2017-87.6 \%$ of men in general and $86.5 \%$ with ischemic stroke, $84.7 \%$ in women in general and $84.2 \%$ with ischemic stroke; in $2018-96.2 \%$ in men in general and $95.9 \%$ with ischemic stroke, $92.5 \%$ 
in women in general and $91.6 \%$ with ischemic stroke; $2019-94.8 \%$ in men in general and $94.8 \%$ with ischemic stroke, $96.0 \%$ in women in general and $95.4 \%$ with ischemic stroke). At the same time, during the years of observation significantly $(p<0.05-0.001)$ decreased the percentage of patients who were taken to the hospital within 1-2 days (in $2017-5.2 \%$ in men in general and $5.6 \%$ with ischemic stroke, $5.7 \%$ in women in general and $6.0 \%$ with ischemic stroke; in $2018-2.2 \%$ in men in general and 2.2 $\%$ with ischemic stroke, $4.3 \%$ in women in general and 4.8 $\%$ with ischemic stroke; in $2019-1.7 \%$ in men in general and $1.6 \%$ with ischemic stroke, $1.1 \%$ in women in general and $1.3 \%$ with ischemic stroke) and more than two days (2017 - $4.6 \%$ in men in general and $4.8 \%$ with ischemic stroke, $6.7 \%$ in women in general and $7.6 \%$ with ischemic stroke; in $2018-1.0 \%$ in men in general and $1.2 \%$ with ischemic stroke, $0.5 \%$ in women in general and $0.6 \%$ with ischemic stroke; in $2019-1.4 \%$ in men in general and 1.2 $\%$ with ischemic stroke, $1.7 \%$ in women in general and 2.8 $\%$ with ischemic stroke) since the onset of stroke.

Positive dynamics of the indicator was also noted in patients of VCCHEMS. Thus, in 2018-2019, compared to 2017 , the percentage of patients who were taken to the institution within 1 day, when the last time there were no signs of stroke, increased significantly $(p<0.01-0.001)(77.8$ $\%$ in 2017 in men in general and $76.9 \%$ with ischemic stroke; in $2019-83.0 \%$ in men in general and $84.0 \%$ with ischemic stroke), significantly $(p<0.05-0.001)$ decreased the percentage of patients who were taken to the hospital within 1-2 days (2017 - $8.8 \%$ for men with ischemic stroke; in $2019-3.7 \%$ for men with ischemic stroke) and more than two days (2017 - $9.1 \%$ for men in general, $10.5 \%$ in women with ischemic stroke; in $2018-5.9 \%$ in women in general and $5.7 \%$ in ischemic stroke; in $2019-3.3 \%$ in men in general and $1.2 \%$ with ischemic stroke, $1.2 \%$ in women in general and $1.3 \%$ with ischemic stroke) since the onset of stroke.

The functional outcome of stroke is due to the severity of neurological deficit, the size of the lesion and is an integral indicator of the effectiveness of treatment and neurorehabilitation $[23,26]$. To assess it, the use of simple functional tests with walking, which do not require expensive equipment and special training, they can be performed in any medical or rehabilitation institution, does not lose its relevance. These tests at the time of discharge from the hospital allow to assess the level of the type of load used in the daily life of patients, ie walking, which contributes to early assessment of rehabilitation potential and competent planning of neurorehabilitation program [18].

In VCCHEMS significantly $(p<0.05-0.001)$ a higher percentage of patients who successfully performed the test "10 meters" (2017 - $52.4 \%$ in men with hemorrhagic stroke; in $2018-64.8 \%$ in men in general and $50.0 \%$ of hemorrhagic stroke) found compared with VRCPNH (2017 $-29.7 \%$ in men with hemorrhagic stroke; in $2018-57.7 \%$ in men in general and $20.4 \%$ with hemorrhagic stroke). When comparing the percentages of other comparison groups (patients in general and patients with ischemic stroke of both sexes), no significant differences were found between medical institutions and in the dynamics. There is approximately the same percentage of patients who did not perform this test in both hospitals (which is on average more than a third). These are patients who, according to statistics $[9,25]$, will find it most difficult to return to the level of daily physical activity they had before, and, even in more favorable cases, they will often need a significant period of time to recover.

One of the reasons for the deterioration of long-term results of stroke treatment is the lack of proper supervision by a vascular neurologist, family doctor and non-compliance with the patient's recommendations received at discharge. Socio-material conditions of the patient also belong to important predictors of favorable prognosis of a stroke. Regular observation of post-stroke patients in the perspective of prevention of ACA reduces mortality during the first year by $25 \%[7,27]$.

The question of the course of stroke in the acute stage has been studied most carefully and most registers give an answer $[8,15,21]$. Six-month surveys were performed in a number of European countries, after which there was a decrease in data from the contingent of stroke survivors or caregivers $[25,26]$. Registers of such a plan allow to obtain only a partial idea of the "portrait" of a stroke patient.

Only a few countries pay special attention to the registration of stroke patients in the longer term [8, 13, 23], which reflects the lack of evidence in this area. Mostly the collection of this information is unsystematic, and therefore the data on assistance are fragmented and random.

In our study, we were able to investigate the more inhospital and pre-hospital stages of stroke management. The outpatient stage is reflected only as an analysis of data on the death of the patient or the institution to which he was sent after discharge.

Thus, when comparing the percentage of patients who were discharged home, it was found significantly $(p<0.05-$ $0.001)$ higher in patients with VCCHEMS (2018 - $83.2 \%$ in men in general, $85.1 \%$ with ischemic stroke and $67.6 \%$ with hemorrhagic stroke, $78.5 \%$ in women in general, 82.1 $\%$ with ischemic stroke and $52.4 \%$ with hemorrhagic stroke; in $2019-80.2 \%$ in men in general and $83.3 \%$ with ischemic stroke, $81.6 \%$ in women in general and $83.0 \%$ with ischemic stroke) compared to VRCPNH (2018 - 62.5 $\%$ in men in general, $67.8 \%$ with ischemic stroke and 31.1 $\%$ with hemorrhagic stroke, $62.6 \%$ in women in general, $68.1 \%$ with ischemic stroke and $19.0 \%$ with hemorrhagic stroke; in $2019-68.6 \%$ for men in general and $72.2 \%$ with ischemic stroke, $66.3 \%$ for women in general and $71.1 \%$ with ischemic stroke).

In 2017, compared to 2018, a significantly higher percentage of women in general and with ischemic stroke who were discharged home was found for VRCPNH 
$(p<0.05)$ (2017 - $73.2 \%$ in women in general and $78.3 \%$ in ischemic stroke; $2018-62.6 \%$ in women in general and $68.1 \%$ with ischemic stroke). And for VCCHEMS in 2017 compared to 2018 found a significantly ( $p<0.05-0.01$ ) lower percentage of patients with ischemic stroke who were discharged home (2017 - $75.0 \%$ in men in general and $77.6 \%$ with ischemic stroke, $78.5 \%$ in women in general and $82.1 \%$ with ischemic stroke; in $2018-83.2 \%$ in men in general and $85.1 \%$ with ischemic stroke, $86.3 \%$ in women in general and $87.9 \%$ with ischemic stroke).

Significantly $(p<0.05)$ a higher percentage of patients transferred to another medical institution was found for VCCHEMS (in $2017-11.0 \%$ in women in general and 8.4 $\%$ in ischemic stroke; in $2018-14.5 \%$ in men in general and $12.4 \%$ in ischemic stroke; in $2019-14.3 \%$ in men in general and $12.3 \%$ in ischemic stroke, $12.9 \%$ in women in general, $12.3 \%$ with ischemic stroke and $40.0 \%$ with hemorrhagic stroke) compared to VRCPNH (2017 - $3.3 \%$ in women in general and $2.2 \%$ with ischemic stroke; in $2018-7.7 \%$ in men in general and $5.6 \%$ with ischemic stroke; in $2019-6.3 \%$ in men in general and $4.8 \%$ with ischemic stroke, $4.0 \%$ in women in general, $4.8 \%$ with ischemic stroke and $0 \%$ with hemorrhagic stroke).

In 2018, compared to 2017 and 2019, a significantly higher percentage of women with strokes who were transferred to another medical institution was established for VRCPNH $(p<0.05-0.01)$ (in $2017-3.3 \%$ of women in general and $2.2 \%$ of ischemic stroke; in $2018-9.6 \%$ in women in general, $8.4 \%$ with ischemic stroke and $19.0 \%$ with hemorrhagic stroke; in $2019-4.0 \%$ in women in general and $0 \%$ with hemorrhagic stroke).

Significantly $(p<0.05-0.001)$ a lower percentage of patients who were referred to a rehabilitation center after discharge was found in VCCHEMS (2017 - $6.3 \%$ in men in general, $5.8 \%$ with ischemic stroke and $9.5 \%$ with hemorrhagic stroke, $2.7 \%$ in women in general, $2.4 \%$ with ischemic stroke and $5.1 \%$ with hemorrhagic stroke; in $2018-1.0 \%$ in men in general, $0.4 \%$ with ischemic stroke and $5.9 \%$ with hemorrhagic stroke, $2.0 \%$ in women in general, $1.1 \%$ with ischemic stroke and $12.5 \%$ with hemorrhagic stroke; in $2019-1.6 \%$ in men in general, 1.2 $\%$ with ischemic stroke and $5.0 \%$ with hemorrhagic stroke, $3.1 \%$ in women in general, $3.3 \%$ with ischemic stroke and $0 \%$ with hemorrhagic stroke) compared to VRCPNH (2017 - $20.2 \%$ in men in general, $18.6 \%$ with ischemic stroke and $32.4 \%$ with hemorrhagic stroke, $18.7 \%$ in women in general, $15.2 \%$ with ischemic stroke and $44.0 \%$ with hemorrhagic stroke; in $2018-25.3 \%$ in men in general, $23.2 \%$ with ischemic stroke and $37.8 \%$ with hemorrhagic stroke, $20.3 \%$ in women in general, $16.9 \%$ with ischemic stroke and $47.6 \%$ with hemorrhagic stroke; $2019-21.3 \%$ for men in general, $19.0 \%$ with ischemic stroke and 35.9 $\%$ with hemorrhagic stroke, $21.1 \%$ for women in general, $17.1 \%$ with ischemic stroke and $47.8 \%$ with hemorrhagic stroke).

In 2017, compared to 2018 and 2019, a significantly higher percentage of patients who were transferred to a rehabilitation center after discharge to the rehabilitation center was found to be significant $(p<0.05-0.001)$ in VCCHEMS (2017 - $6.3 \%$ in men in general and $5.8 \%$ in ischemic patients. Stroke; in $2018-1.0 \%$ in men in general and $0.4 \%$ with ischemic stroke; in $2019-1.6 \%$ in men in general and $1.2 \%$ with ischemic stroke). That is, over time, fewer and fewer patients are able to receive treatment at a neurorehabilitation center.

Significantly $(p<0.05-0.001)$ a higher percentage of patients who died in hospital $(2017-8.3 \%$ in men in general, $6.5 \%$ with ischemic stroke and $19.0 \%$ with hemorrhagic stroke) was found in VCCHEMS. It is impossible to compare this indicator between medical institutions for 2018-2019, because patients who were admitted to VCCHEMS and their condition was regarded as severe and extremely severe, were transferred to the intensive care unit. Accordingly, data on their deaths were not recorded.

As a result of our study, a certain inconsistency of data concerning the average scores and values that are expressed in absolute numbers. If we consider the average scores, then on the Glasgow com scale, all patients were in a state of clear consciousness or stun, and on the NIHSS stroke scale - had a maximum of 20 points. As we see, the contingent of patients by the severity of the condition, the degree of loss of consciousness, neurological deficit, the time of delivery to the hospital after a stroke is quite variable. Therefore, the statistical analysis cannot be limited to averages, because the general favorable averages can "hide" serious problems and shortcomings, or, conversely, progressive trends [14].

That is why the use of average indicators of annual reporting of neurological clinics, which insignificantly and incorrectly reflect the effectiveness of medical care and the patient's condition, should be a thing of the past. The registry method aims to: ensure that the assessment of the quality of health care is truly meaningful, covering all elements of care provided to patients with ACA, including its structure, process and outcomes; that criteria such as effectiveness, accessibility, relevance, acceptability, effectiveness and efficiency be used to assess the quality of care provided; and that when comparing the results in terms of time or between different medical institutions, it is necessary to take into account differences in the composition of the patient population.

\section{Conclusions and prospects for further research}

1. Comparison of the data of the territorial-population register of stroke in hospitals in Vinnytsia in 2017-2019 showed that in both studied institutions the percentage of patients delivered to the hospital up to 1 day increased and the time from the onset of stroke symptoms to hospitalization decreased. However, the degree of functional deficit in patients discharged from both hospitals did not differ significantly. In 2019 in VRCPNH, compared 
to previous years and compared to VCCHEMS, a higher percentage of patients with severe stroke and patients who

\section{References}

1. Belova, A. N. (2004). Shkaly’, testy` i oprosniki v nevrologii i nejrokhirurgii [Scales, tests and questionnaires in neurology and neurosurgery]. M.: Izd-vo Samarskij dom pechati - M.: Publishing house Samara Printing House.

2. Bokeryia, L. A., Pokrovskyi, A. V., Sokurenko, G. Yu., Samorodskaia, I. V., Abuhov, S. A., \& Alekian, B. G. (2013) Naczional`ny`e rekomendaczii po vedeniyu paczientov $s$ zabolevaniyami brakhioczefal'ny 'kh arterij [National guidelines for the management of patients with brachiocephalic artery disease]. Rossijskij soglasitel’ny`j dokument - Russian consensus document.

3. Bondar, O. B., Pershyna, Yu. V., Ybrahymova, E. L., \& Bondar, B. E. (2010). Rol' klinicheskikh shkal v oczenke ostrogo vosstanovitel'nogo periodov insul' ta [The role of clinical scales in assessing the acute and recovery periods of stroke]. Ukrayins 'kij vi snik psikhonevrologi yi - Ukrainian Bulletin of Psychoneurology, 18, (4), 10-15.

4. Bykov, A. T., \& Maliarenko, T. N. (2013). Fizicheskaya aktivnost kak vazhnejshij komponent pervichnoj i vtorichnoj profilaktiki insul'ta [Physical activity as an essential component of primary and secondary stroke prevention]. Mediczinskij zhurnal Medical journal, 2, 4-8.

5. Gusev, E. I., Vylenskyi, B. S., \& Skoromets, A. A. (1995) Osnovny`e faktory', vliyayushhie na iskhody insul tov [Key factors affecting stroke outcomes]. Zhurnal nevrologii i psikhiatrii im. S.S. Korsakova - Journal of Neurology and Psychiatry n.a. S. S. Korsakov, 95 (1), 4-7.

6. Evtushenko, C. K., Yanovskaia, N. V., Sukhonosova, O. Yu., Omelianenko, A. A., \& Fomycheva, E. M. (2015). Shkaly` v obshhej i detskoj nevrologii. Nauchno-prakticheskoe i metodicheskoe posobie. S. K. Evtushenko (Red.). [Scales in general and pediatric neurology. Scientific and practical and methodological manual. S. K. Evtushenko (Ed.)]. Izdatel'skij dom: Zaslavskij A.Yu. - Publishing House: Zaslavsky A.Yu.

7. Kosyvtsova, O. V. (2014). Vedenie paczientov v vosstanovitel'nom periode insul'ta [Management of patients in the recovery period of a stroke]. Nevrologiya, nejropsikhiatriya, psikhosomatika - Neurology, neuropsychiatry, psychosomatics, (4), 101-105.

8. Martsevych, S. Yu., Kutyshenko, N. P., Suvorov, A. Yu., Gynzburh, M. L., Deev, A. D., \& Boitsov, S. A. (2015). Analiz anamnesticheskikh faktorov i ikh rol ' v opredelenii blizhajshego (gospital `nogo) prognoza u bol’ny`kh, perenesshikh mozgovo insul't ili tranzitornuyu ishemicheskuyu ataku. Rezul'taty' registra LIS-2 [Analysis of anamnestic factors and their role in determining the closest (hospital) prognosis in patients after a stroke or transient ischemic attack. LIS-2 register results]. Rossijskij kardiologicheskij zhurnal - Russian Journal of Cardiology, 6 (122), 14-19.

9. Merkholts, Ya., Karr, L. Kh., \& Flemyh, K. (2014). Rannyaya reabilitacziya posle insul'ta [Early rehabilitation after a stroke]. M.: MEDpress-inform - M.: MEDpress-inform.

10. Bayraktar, Y. S., Sahinoglu, M., Cicekci, F., Inci, K. A. R. A., Karabagli, H., Duman, A., \& Celik, J. B. (2019). Comparison of Glasgow Coma Scale and Full Outline of Unresponsiveness (Four) Score: A Prospective Study. Turkish neurosurgery, 29 (2), 1-4. doi: 10.5137/1019-5149.JTN.24175-18.2.

11. Brott, T., Adams Jr, H. P., Olinger, C. P., Marler, J. R., Barsan, W. G., Biller, J., ... \& Hertzberg, V. (1989). Measurements of acute cerebral infarction: a clinical examination scale. Stroke, 20 (7), 864-870. doi: 10.1161/01.str.20.7.864.

12. Broughton, B. R. S., Reutens, D. C., \& Sobey, C. G. (2009) received special care in neurorehabilitation centers after discharge.

Apoptotic Mechanisms after Cerebral Ischemia. Stroke, 40, e331-e339. doi: 10.1161/STROKEAHA.108.531632.

13. Cabral, N. L., Nagel, V., Conforto, A. B., Amaral, C. H., Venancio, V. G., Safanelli, J., ... \& Zetola, V. D. H. F. (2018). Five-year survival, disability, and recurrence after first-ever stroke in a middle-income country: a population-based study in Joinvile, Brazil. International Journal of Stroke, 13 (7), 725-733. doi: 10.1177/1747493018763906.

14. Etches, V., Frank, J., Di Ruggiero, E., \& Manuel, D. (2006). Measuring population health: A review of indicators. Annu. Rev. Public Health, 27, 29-55. doi: 10.1146/ annurev.publhealth.27.021405.102141.

15. Fang, M. C., Go, A. S., Chang, Y., Borowsky, L. H., Pomernacki, N. K., Udaltsova, N., \& Singer, D. E. (2014). Long-term survival after ischemic stroke in patients with atrial fibrillation. Neurology, 82 (12), 1033-1037. doi: 10.1212/WNL.0000000000000248.

16. Feng, W., \& Belagaje, S. R. (2013, November). Recent advances in stroke recovery and rehabilitation. In Seminars in neurology (Vol. 33, No. 05, pp. 498-506). Thieme Medical Publishers. doi: 10.1055/s-0033-1364215.

17. Furie, K. L., Kasner, S. E., Adams, R. J., Albers, G. W., Bush, R. L., Fagan, S. C., ... \& Mitchell, P. H. (2011). Guidelines for the prevention of stroke in patients with stroke or transient ischemic attack: a guideline for healthcare professionals from the American Heart Association/American Stroke Association. Stroke, 42 (1), 227-276. doi: 10.1161/STR.0b013e3181f7d043.

18. Hobart, J. C., Cano, S. J., Zajicek, J. P., \& Thompson, A. J. (2007). Rating scales as outcome measures for clinical trials in neurology: problems, solutions, and recommendations. The Lancet Neurology, 6 (12), 1094-1105. doi: 10.1016/S14744422(07)70290-9.

19. Karabiyik, L. (2010). Intensive care scoring systems. Turkish Journal of Intensive Care Medicine, 9 (3), 129-143.

20. Khanal, K., Bhandari, S. S., Shrestha, N., Acharya, S. P., \& Marhatta, M. N. (2016). Comparison of outcome predictions by the Glasgow coma scale and the Full Outline of UnResponsiveness score in the neurological and neurosurgical patients in the Intensive Care Unit. Indian journal of critical care medicine: peer-reviewed, official publication of Indian Society of Critical Care Medicine, 20 (8), 473-476. doi: 10.4103/0972-5229.188199.

21. Kim, D., Lee, S. H., Joon Kim, B., Jung, K. H., Yu, K. H., Lee, B. C., ... \& Korean Stroke Registry investigators. (2013). Secondary prevention by stroke subtype: a nationwide followup study in 46108 patients after acute ischaemic stroke. European heart journal, 34 (35), 2760-2767. doi: 10.1093/ eurheartj/eht185

22. Prabhakaran, S., Zarahn, E., Riley, C., Speizer, A., Chong, J. Y., Lazar, R. M., ... \& Krakauer, J. W. (2008). Inter-individual variability in the capacity for motor recovery after ischemic stroke. Neurorehabilitation and neural repair, 22 (1), 64-71. doi: $10.1177 / 1545968307305302$.

23. Sarfo, F. S., Akassi, J., Kyem, G., Adamu, S., Awuah, D., Kantanka, O. S., \& Ovbiagele, B. (2018). Long-term outcomes of stroke in a Ghanaian outpatient clinic. Journal of Stroke and Cerebrovascular Diseases, 27 (4), 1090-1099. doi: 10.1016/j.jstrokecerebrovasdis.2017.11.017.

24. Teasdale, G., \& Jennett, B. (1974). Assessment of coma and impaired consciousness: a practical scale. The Lancet, 304 (7872), 81-84. doi: 10.1016/s0140-6736(74)91639-0.

25. Thrift, A. G., Thayabaranathan, T., Howard, G., Howard, V. J., Rothwell, P. M., Feigin, V. L., ... \& Cadilhac, D. A. (2017). Global 
stroke statistics. International Journal of Stroke, 12 (1), 1332. doi: 10.1177/17474993016676285.

26. VanSwearingen, J. M., Perera, S., Brach, J. S., Wert, D., \& Studenski, S. A. (2011). Impact of exercise to improve gait efficiency on activity and participation in older adults with mobility limitations: a randomized controlled trial. Physical therapy, 91 (12), 1740-1751. doi: 10.2522/ptj.20100391.

27. Webster, F., Saposnik, G., Kapral, M. K., Fang, J., O'Callaghan, C., \& Hachinski, V. (2011). Organized outpatient care: stroke prevention clinic referrals are associated with reduced mortality after transient ischemic attack and ischemic stroke. Stroke, 42 (11), 3176-3182. doi: 10.1161/STROKEAHA.111.621524.

\section{Список посилань}

1. Белова, А. Н. (2004). Шкалы, тесты и опросники в неврологии и нейрохирургии. М.: Изд-во Самарский дом печати.

2. Бокерия, Л. А., Покровский, А. В., Сокуренко, Г. Ю., Самородская, И. В., Абугов, С. А., \& Алекян, Б. Г. (2013). Национальные рекомендации по ведению пациентов с заболеваниями брахиоцефальных артерий. Российский согласительный документ.

3. Бондарь, О. Б., Першина, Ю. В., Ибрагимова, Е. Л., \& Бондарь, Б. Е. (2010). Роль клинических шкал в оценке острого и восстановительного периодов инсульта. Український вісник психоневрології, 18 (4), 10-15.

4. Быков, А. Т., \& Маляренко, Т. Н. (2013). Физическая активность как важнейший компонент первичной и вторичной профилактики инсульта. Медицинский журнал, 2, 4-8.

5. Гусев, Е. И., Виленский, Б. С., \& Скоромец, А. А. (1995). Основные факторы, влияющие на исходы инсультов. Журнал неврологии и психиатрии им. С.С. Корсакова, 95 (1), 4-7.

6. Евтушенко, С. К., Яновская, Н. В., Сухоносова, О. Ю., Омельяненко, А. А., \& Фомичева, Е. М. (2015). Шкалы в общей и детской неврологии. Научно-практическое и методическое пособие. С. К. Евтушенко (Ред.). Издательский дом: Заславский А.Ю.

7. Косивцова, О. В. (2014). Ведение пациентов в восстановительном периоде инсульта. Неврология, нейропсихиатрия, психосоматика, 4, 101-105.

8. Марцевич, С. Ю., Кутишенко, Н. П., Суворов, А. Ю., Гинзбург, М. Л., Деев, А. Д., \& Бойцов, С. А. (2015). Анализ анамнестических фракторов и их роль в определении ближайшего (госпитального) прогноза у больных, перенесших мозговой инсульт или транзиторную ишемическую атаку. Результаты регистра ЛИС-2. Российский кардиологический журнал, 6 (122), 14-19.

9. Мерхольц, Я., Карр, Д. Х., \& Флемиг, К. (2014). Ранняя реабилитация после инсульта. М.: МЕДпресс-информ.

10. Bayraktar, Y. S., Sahinoglu, M., Cicekci, F., Inci, K. A. R. A., Karabagli, H., Duman, A., \& Celik, J. B. (2019). Comparison of Glasgow Coma Scale and Full Outline of Unresponsiveness (Four) Score: A Prospective Study. Turkish neurosurgery, 29 (2), 1-4. doi: 10.5137/1019-5149.JTN.24175-18.2.

11. Brott, T., Adams Jr, H. P., Olinger, C. P., Marler, J. R., Barsan, W. G., Biller, J., ... \& Hertzberg, V. (1989). Measurements of acute cerebral infarction: a clinical examination scale. Stroke, 20 (7), 864-870. doi: 10.1161/01.str.20.7.864

12. Broughton, B. R. S., Reutens, D. C., \& Sobey, C. G. (2009). Apoptotic Mechanisms after Cerebral Ischemia. Stroke, 40, e331-e339. doi: 10.1161/STROKEAHA.108.531632.

13. Cabral, N. L., Nagel, V., Conforto, A. B., Amaral, C. H., Venancio, V. G., Safanelli, J., ... \& Zetola, V. D. H. F. (2018). Five-year survival, disability, and recurrence after first-ever stroke in a middle-income country: a population-based study in Joinvile, Brazil. International Journal of Stroke, 13 (7), 725-733. doi:
$10.1177 / 1747493018763906$

14. Etches, V., Frank, J., Di Ruggiero, E., \& Manuel, D. (2006). Measuring population health: A review of indicators. Annu. Rev. Public Health, 27, 29-55. doi: 10.1146/ annurev.publhealth.27.021405.102141.

15. Fang, M. C., Go, A. S., Chang, Y., Borowsky, L. H., Pomernacki, N. K., Udaltsova, N., \& Singer, D. E. (2014). Long-term survival after ischemic stroke in patients with atrial fibrillation. Neurology, 82 (12), 1033-1037. doi: 10.1212/WNL.0000000000000248.

16. Feng, W., \& Belagaje, S. R. (2013, November). Recent advances in stroke recovery and rehabilitation. In Seminars in neurology (Vol. 33, No. 05, pp. 498-506). Thieme Medical Publishers. doi: 10.1055/s-0033-1364215

17. Furie, K. L., Kasner, S. E., Adams, R. J., Albers, G. W., Bush, R. L., Fagan, S. C., ... \& Mitchell, P. H. (2011). Guidelines for the prevention of stroke in patients with stroke or transient ischemic attack: a guideline for healthcare professionals from the American Heart Association/American Stroke Association. Stroke, 42 (1), 227-276. doi: 10.1161/STR.0b013e3181f7d043.

18. Hobart, J. C., Cano, S. J., Zajicek, J. P., \& Thompson, A. J. (2007). Rating scales as outcome measures for clinical trials in neurology: problems, solutions, and recommendations. The Lancet Neurology, 6 (12), 1094-1105. doi: 10.1016/S14744422(07)70290-9.

19. Karabiyik, L. (2010). Intensive care scoring systems. Turkish Journal of Intensive Care Medicine, 9 (3), 129-143.

20. Khanal, K., Bhandari, S. S., Shrestha, N., Acharya, S. P., \& Marhatta, M. N. (2016). Comparison of outcome predictions by the Glasgow coma scale and the Full Outline of UnResponsiveness score in the neurological and neurosurgical patients in the Intensive Care Unit. Indian journal of critical care medicine: peer-reviewed, official publication of Indian Society of Critical Care Medicine, 20 (8), 473-476. doi: 10.4103/0972-5229.188199.

21. Kim, D., Lee, S. H., Joon Kim, B., Jung, K. H., Yu, K. H., Lee, B. C., ... \& Korean Stroke Registry investigators. (2013). Secondary prevention by stroke subtype: a nationwide followup study in 46108 patients after acute ischaemic stroke. European heart journal, 34 (35), 2760-2767. doi: 10.1093/ eurhearti/eht185.

22. Prabhakaran, S., Zarahn, E., Riley, C., Speizer, A., Chong, J. Y., Lazar, R. M., ... \& Krakauer, J. W. (2008). Inter-individual variability in the capacity for motor recovery after ischemic stroke. Neurorehabilitation and neural repair, 22 (1), 64-71. doi: $10.1177 / 1545968307305302$

23. Sarfo, F. S., Akassi, J., Kyem, G., Adamu, S., Awuah, D., Kantanka, O. S., \& Ovbiagele, B. (2018). Long-term outcomes of stroke in a Ghanaian outpatient clinic. Journal of Stroke and Cerebrovascular Diseases, 27 (4), 1090-1099. doi: 10.1016/j.jstrokecerebrovasdis.2017.11.017.

24. Teasdale, G., \& Jennett, B. (1974). Assessment of coma and impaired consciousness: a practical scale. The Lancet, 304 (7872), 81-84. doi: 10.1016/s0140-6736(74)91639-0.

25. Thrift, A. G., Thayabaranathan, T., Howard, G., Howard, V. J., Rothwell, P. M., Feigin, V. L., ... \& Cadilhac, D. A. (2017). Global stroke statistics. International Journal of Stroke, 12 (1), 1332. doi: $10.1177 / 1747493016676285$.

26. VanSwearingen, J. M., Perera, S., Brach, J. S., Wert, D., \& Studenski, S. A. (2011). Impact of exercise to improve gait efficiency on activity and participation in older adults with mobility limitations: a randomized controlled trial. Physical therapy, 91 (12), 1740-1751. doi: 10.2522/ptj.20100391.

27. Webster, F., Saposnik, G., Kapral, M. K., Fang, J., O'Callaghan, C., \& Hachinski, V. (2011). Organized outpatient care: stroke prevention clinic referrals are associated with reduced mortality after transient ischemic attack and ischemic stroke. Stroke, 42 (11), 3176-3182. doi: 10.1161/STROKEAHA.111.621524. 
РЕЗУЛЬТАТИ ОЦІНКИ СТАНУ НА МОМЕНТ ПОСТУПЛЕННЯ В СТАЦІОНАР, ФУНКЦІОНАЛЬНОГО РЕЗУЛЬТАТУ НА МОМЕНТ ВИПИСКИ ТА ПЛАНУВАННЯ АМБУЛАТОРНОГО ЕТАПУ У ІНСУЛЬТНИХ ПАЦІЄНТІВ ЗА ДАНИМИ РЕГІСТРУ ЛІКАРЕНЬ м. ВІННИЦІ ЗА 2017-2019 РОКИ

\section{Фікс Д. 0.}

Анотація. Удосконалення підходів до діагностики, терапії та реабілітації інсульту є першорядною задачею, оскільки дане захворювання становить не лише медичну, а і соціальну проблему. Мета роботи - оцінити динаміку показників стану на момент поступлення в стаціонар, функціонального результату на момент виписки та планування амбулаторного етапу в інсультних пацієнтів лікарень м. Вінниці за період 2017-2019 рр. Регістр інсульту сформовано на базі медичної документації лікувальних закладів, які є найбільш типовими для даного регіону Украӥни. Статистична обробка результатів проведена за допомогою ліцензійного статистичного пакету "Statistica 5.5" з використанням параметричних методів оцінки. Встановлено достовірні відмінності показників ефективності організації медичної допомоги при інсульті на догоспітальному та госпітальному етапі між двома лікувальними закладами м. Вінниця, а також у динаміці часу спостереження. Проаналізовано позитивні та негативні сторони лікувально-діагностичної роботі даних стаціонарів. Проаналізовано ряд фракторів, що впливають на успішність результату лікування та комплексної реабілітації пацієнтів, які перенесли інсульт. Представлені сучасні погляди на проблему аналізу клінічних даних за допомогою методу регістра та медичної статистики.

Ключові слова: інсульт, шкала ком Глазго, шкала інсульту NIHSS, каротидна ангіопластика, ффункціональний тест ходьби, нейрореабілітація.

\section{РЕЗУЛЬТАТЫ ОЦЕНКИ СОСТОЯНИЯ НА МОМЕНТ ПОСТУПЛЕНИЯ В СТАЦИОНАР, ФУНКЦИОНАЛЬНОГО РЕЗУЛЬТАТА НА МОМЕНТ ВЫПИСКИ И ПЛАНИРОВАНИЯ АМБУЛАТОРНОГО ЭТАПА У ИНСУЛЬТНЫХ ПАЦИЕНТОВ ПО ДАННЫМ РЕГИСТРА БОЛЬНИЦ г. ВИНнИЦЫ ЗА 2017-2019 гОДЫ}

Фикс Д. А.

Аннотация. Совершенствование подходов к диагностике, терапии и реабилитации инсульта является первостепенной задачей, поскольку данное заболевание представляет не только медицинскую, но и социальную проблему. Цель работы оценить динамику показателей состояния на момент поступления в стационар, фрункционального результата на момент выписки и планирования амбулаторного этапа в инсультных пациентов больниц г. Винницы за период 2017-2019 г2. Регистр инсульта сфрормирован на базе медицинской документации лечебных учреждений, которые являются наиболее типичными для данного региона Украины. Статистическая обработка результатов проведена с помощью лицензионного статистического пакета "Statistica 5.5" с использованием параметрических методов оценки. Установлено достоверные различия показателей эфрфективности организации медицинской помощи при инсульте на догоспитальном и госпитальном этапе между двумя лечебными заведениями г. Винница, а также в динамике времени наблюдения. Проанализированы положительные и отрицательные стороны лечебно-диагностической работы данных стационаров. Проанализирован ряд фракторов, влияющих на успешность результата лечения и комплексной реабилитации пациентов, перенесших инсульт. Представлены современные взгляды на проблему анализа клинических данных с помощью метода регистра и медицинской статистики.

Ключевые слова: инсульт, шкала ком Глазго, шкала инсульта NIHSS, каротидная ангиопластика, функциональный тест ходьбы, нейрореабилитация. 